\title{
Research on the Design and Development of the Undergraduate Syllabus of Gauhati University
}

\author{
Rashri Duzta \\ Lecturer, Biswanath College of Education, Biswanath, Assam, India \\ rajashridutta16@gmail.com
}

\begin{abstract}
In India to develop the professional skills of the teachers NCTE (National Council for Teacher Education) provides B. Ed. course especially for secondary school teachers to consolidate their knowledge and look into the teaching profession from a broader perspective. In this paper a detailed study on B. Ed. course syllabus of Gauhati University which includes the course content, objectives and methods of teaching, use of technology in teaching and other aspects of the B. Ed. syllabus is carried out. Special emphasis has been given on the design and development of the one year and two year B. Ed. course syllabus. The interview method is adopted in this study. In the study it is found that the B. Ed. trainees have high expectations from the programme and they seek for improvement of the syllabus in some specific areas.
\end{abstract}

Keywords: Syllabus, B. Ed. course, Teacher Education

\section{Introduction}

The seed of development of a country mainly depends on education. Education is the back bone of any society and the nation. Without education there can be no developments in the field of science, economy, art, medicine, music or any other fields of knowledge in a country. Education implies a form of learning in which knowledge, skills and habits are transferred from one generation to the next generation. Education is a tripolar process which includes teacher, student and curriculum. Curriculum consists of several components like objectives, attitudes, time table, duration, classroom activities, syllabus, materials, study skills, language skills, evaluation procedure etc. Before setting up a program or a course, these components should be determined and described in detail. In fact, these elements help to clarify various dimensions of the curriculum and consequently enhance its productivity. Therefore, curriculum or course designers need to scrutinize these components one by one and determine their roles in the program.

A syllabus is the most important part of the curriculum. Syllabus usually refers to the program or outline of a course of study. The units and topics included by the syllabus constructor must be learnt by the students which in turn will increase the knowledge of the students on a particular subject. In the syllabus the syllabus constructor should arrange the topics in a sequence and a logical manner. In India the syllabus is prescribed once in a year and the particular syllabus that is prescribed for the year should be completed both by the teacher and the student during the year. Examinations will be conducted at the end of the year only from the particular syllabus of the year in the particular subject in order to evaluate the knowledge of the students.

In India to develop the professional skills of the teachers NCTE (National Council for Teacher Education) provides many in - service and pre - service courses for primary and secondary school teachers. B. Ed. or Bachelor of Education is the one among such courses. It is a bachelor's degree undertaken to take up teaching as a profession. This course helps the candidates to consolidate their knowledge and look into the teaching profession from a broader perspective Candidates will be able to recognize various educational issues at a larger level. The candidates also acquire qualities such as recognizing the role and importance of a teacher in the socio - cultural and education systems and enhance the knowledge regarding the secondary school students. It helps to understand the psychology of the learners as a child and as an adolescent. The B. Ed. course gives opportunity to know about the (a) perspective in education which includes child development and adolescence, contemporary India and education, teaching - learning process, philosophy and sociology etc. (b) curriculum and pedagogic studies which focuses on theories of learning, critical understanding of the school curriculum, pedagogic knowledge about science, mathematics, languages and other specific areas, knowledge of community etc. . This course also includes practicum and school internship to develop various skills through the practical trainings.

In the real life scenario in the secondary schools of Assam it is observed that most of the teachers with the B. Ed. degree fail to apply various methods, techniques, psychological theories in the real classroom scenario. They are not able to develop the appropriate skills and feel the difficulties regarding gender equality, individual differences, and maxims of teaching, interrelationship among the teachers pupil - community. Because of these drawbacks the classroom teaching fails to meet the expectations of the learners. So it is difficult to differentiate the teaching process between a trained teacher with B. Ed. and an untrained teacher.

In the light of the above discussion some questions arise regarding the B. Ed. course like 'Is there any drawback in the B. Ed. course?', 'Did the trainees experiences any difficulties during training period?'; 'Is the curriculum or the course content sufficient for professional development of the teacher trainees?' So a detailed study becomes necessary on the syllabus of both one year and two year B. Ed. course. In order to do so it is required to study the course content, objectives, methods of teaching, use of technology in teaching and other aspects of the B. Ed. syllabus. So this 
study is conducted to a detail study on the one year and two year B. Ed. syllabuses under Gauhati University.

\section{Operational definition}

B. Ed. syllabus: B. Ed. syllabus means the syllabus followed by the government and private B. Ed. Colleges under Gauhati University and which is prepared as per the guidelines of the NCTE. There are two B. Ed. syllabuses under two academic sessions viz. one year B. Ed. syllabus and two year B. Ed. syllabus. The syllabuses of Gauhati University are published by "The Academic Council of Gauhati University".

\section{Objectives of the study undertaken:}

1) To study the relevancy of the contents and provisions of the syllabus of one year B. Ed. course.

2) To study the relevancy of the contents and provisions of the syllabus of revised two year B. Ed. course.

3) To analyze and compare the syllabus of one year and revised two year B. Ed. course.

\section{Delimitation of the study}

The study has been concluded extremely academic purpose only. It has been delimited as,

1) The research study was confined to Gauhati university B. Ed. syllabus only.

2) The research study has been confined only to the core content of the Gauhati University B. Ed. syllabus.

3) The data collection for the study is confined within the affiliated private B. Ed. colleges under Gauhati University only.

\section{Literature Review}

Sushma, (2014), conducted a study on "attitude of teacher educators towards two years B. Ed. programme" by aided and unaided teacher educators towards two years B. Ed. programme. Adhikary (2017), conducted a study on "A study on the perception of the teacher trainees towards two year B. Ed. programme implemented in the teacher education institutions in Assam". She found both male and female trainees are somewhat dissatisfied with the availability of the resources. The dissatisfied percentage of B. Ed. trainees towards curriculum distribution of two year B. Ed. programme is comparatively more than satisfied trainees. Khan (2017), conducted a study on "Implementation of Two year B. Ed. program: Issues and Concerns". He concluded that most of the teachers agree that internship schools are not cooperating well in the extended year B. Ed. program. Majority of the teacher educators also agreed that the extended B. Ed. program is still in better implementation in central universities but in state universities and in private institution the condition is miserable especially in terms of internship program. In these studies it was found that the B. Ed. trainees and the teachers gave mixed responses about the B. Ed. course. But most of the researchers found negative responses towards the course structure, availability of resources, course fees, the course contents etc. Moreover there is no proper study found regarding the transaction of the B. Ed. syllabus from one year to two year under Gauhati University. So after considering all the facts the necessity of a study on the B. Ed. syllabus under Gauhati University and the responses of the trainees about this course arise.

\section{Methodology}

The descriptive method was adopted to conduct the study. In the present study 75 sample trainees took randomly from different B. Ed. colleges of Assam under Gauhati University. Both Primary and Secondary sources were used for the study. For purposes of collection of Primary data interview technique was used.

\section{Major Findings}

1) It has been found that $94.1 \%$ trainees are not satisfy with the teaching strategies and 5.9\% are satisfied. Most of the trainees argue that although there are various methods of teaching included in the B. Ed. syllabus, but it is seen that in the real classroom scenario the teachers are usually use the lecture cum discussion method rather than learning by doing method.

2) It has been found that $79.4 \%$ trainee agree that the present Gauhati University B. Ed. syllabus is helpful to train the teacher to use the modern technology in the real classroom scenario and $20.6 \%$ disagree with it. They said that in their colleges the teacher never used computer and power point presentation in classroom teaching. So they are unable to learn the use of various technology in education for develop their professional skill.

3) It has been found that $73.5 \%$ trainee have opinion that all the units of the core papers included in the two year B. Ed. syllabus is useful. But $26.5 \%$ trainees disagree with that. According to them some topics which have not any relevancy to fulfill the objectives of the course.

4) It has been found that $82.4 \%$ trainees think that the two year duration of the revised syllabus is appropriate while $17.6 \%$ trainees do not agree with that fact. They prefer the one year B. Ed. course over the newly revised two year B. Ed. course from durability and economic point of view.

5) After thorough analysis of the contents of both syllabus it is found that the two year B. Ed. syllabus give importance on skill development, use of ICT, modern concern of education, practice teaching etc. But in the syllabus the content writer has not properly explained the assessment procedures of internal marks and due to lack of proper guidelines some difficulties may arise in the process of proper evaluation of the trainees.

\section{Conclusion}

On the basis of the above study it can be observed that the present two year B. Ed. syllabus has received some mixed response from the present $\mathrm{B}$. Ed. trainees and the syllabus has scopes of improvement in many areas. Through interview it is found that trainees have high expectations from the programme and they seek for improvement of the syllabus in some specific areas. From the analysis and findings it is observed that the two year B. Ed. syllabus is in the category of 'Topic based syllabus' 
The two year B. Ed. course is an ideal duration for preparing the teacher trainees who intern will involve themselves in making the students to be a good and responsible citizen throughout their lives. If the syllabus constructor will pay more attention while preparing the $\mathrm{B}$. Ed. syllabus then there will be no lacuna left in the teacher education programme.

\section{References}

[1] Khatun, Reshma, and Nasir Ahmed. "Teacher education in India: A historical perspective. " Teacher education 3.2 (2018).

[2] Chakrabarty, Parijat, and D. Chakrabarty. "Implementation of Internship in 2 Year B. Ed. Course-A Challenge or Routine Task."

[3] Adhikary, A. "A study on the perception of the teacher trainees towards two - year B. Ed. programme implemented in the teacher education institutions in Assam. " International Journal of Scientific and Research Publications 7.9 (2017): 385.

[4] Gorain, Ramanath. "Views of Teacher educators towards Two - year B. Ed. Programme of West Bengal. " International Journal of Interdisciplinary and Multidisciplinary Studies (IJIMS) 4.2 (2017): 95 98.

[5] Garcha, Pargat Singh. "Reflections on two years teacher education programme. " International Journal of Education 6 (2016): 69 - 74.

[6] RAJPUT, SANJAY B. "Issues of B. Ed. Programme in terms one year or two years and Teaching Learning Process: Some Observations and Reflections."

[7] Sales, Auxiliadora, Joan A. Traver, and Rafaela García. "Action research as a school - based strategy in intercultural professional development for teachers. " Teaching and Teacher Education 27.5 (2011): 911 919.

[8] Girvan, Carina, Claire Conneely, and Brendan Tangney. "Extending experiential learning in teacher professional development. " Teaching and teacher education 58 (2016): 129 - 139.

[9] Lokesh, Koul. Methodology of educational research. Vikas publishing house, 1984.

[10] S. R. VASHST, Prospective in curriculum development, Anmol Publications.

[11] Ram, Ahuja, Research Methods, Rawat Publications, 2011 